\title{
Aplikasi Penentuan Tingkat Kesegaran Ikan Selar Berbasis Citra Digital Dengan Metode Kuadrat Terkecil
}

\author{
Defit Bee ${ }^{1}$, Winsy Ch. D. Weku², Altien J. Rindengan ${ }^{3 *}$ \\ 1,2,3 Program Studi Matematika, Fakultas Matematika dan Ilmu Pengetahuan Alam, \\ Universitas Sam Ratulangi Manado \\ *corresponding author email: altien@unsrat.ac.id
}

\begin{abstract}
Abstrak
Ikan banyak mengandung nutrisi yang sangat bermanfaat bagi tubuh, namun seringkali ikan diperdagangkan dalam keadaan sudah mati juga dalam keadaan masih hidup. Untuk mengamati kesegaran ikan selar dilakukan dengan pengenalan perubahan warna yang tampak pada citra digital dengn menggunakan metode kuadrat terkecil. Tujuan dari penelitian ini adalah membangun sistem aplikasi pengelolahan citra untuk mendeteksi tingkat kesegaran ikan selar. Data yang gunakan adalah 10 sampel citra ikan selar yang di-photo setiap 1 jam selama 15 jam dan diperoleh 150 data gambar kemudian diolah dan dilakukan analisis dengan metode kuadrat terkecil. Proses pertama diawali dengan pengolahan citra dengan melakukan pemtotongan (cropping) pada bagian tepi mata citra original kemudian dilanjutkan dengan penyamaan ukuran (resize) menjadi 1000 x 1000 pixel dan pergantian format citra menjadi *.png. setelah gambar sudah diolah kemudian dilakukan perhitungan nilai rata-rata grayscale menggunakakn sistem aplikasi 'Rata rataGambar' dan diperoleh persamaan yang disimpan sebagai data training pada sistem aplikasi. Setelah citra sudah diolah selanjutnya citra tersebut di-input pada sistem maka citra akan dikonversi kedalam bentuk grayscale dan ditampilkan pada tempat yang telah ditentukan bersamaan dengan histogram rgb dan grayscale kemudian dilakukan perhitungan dengan metode kuadrat terkecil. Proses terakhir kita lakukan pencocokan citra uji dengan citra yang disimpan sebagai data training dan diperoleh kesimpulan apakah citra itu (sangat segar, segar, cukup segar, tidak segar, atau sangat tidak segar ), persentase ketidaksegaran ikan selar, dan lama waktu ikan selar mati. Penelitian ini menggunakan 150 sampel citra ikan selar dari ikan masih sangat segar sampai ikan sangat tidak segar (busuk) hasilnya menunjukan 125 citra sesuai dan 25 tidak sesuai dengan persentase akurasi sistem sebesar $83.333 \%$.
\end{abstract}

Kata kunci : Mata Ikan Selar, Pengolahan Citra Digital, Metode Kuadrat Terkecil.

\section{Application Of Mackerel Freshness Level Determination Based On Digital Image With Least Square Method}

\begin{abstract}
Fish contains lots of nutrients which are beneficial for human body. However, fish are mostly traded in two conditions, both dead and alive. Discoloration detection on digital image using least square method is conducted to observe the freshness level of mackerel. This research aims at constructing image processing application system to detect mackerel freshness level. Data used was 10 samples of mackerel image which were captured every hour in 15 hour duration. 150 image data were then being processed and analyzed using least square method. First step was image processing which was started by cropping the edge of original eye image followed by resizing the image into $1000 x$ 1000 pixel each and changing image file format into *.png. After that, the process was continued by applying 'Rata rataGambar' to calculate grayscale average point. This resulted in an equation which was saved as data training in application system. Once the image was processed, it was then input into system. Thus it would be converted to grayscale form and shown in the determined location along with rgb and grayscale histogram which then followed by least square method. The last step was comparing testing image to image saved as data training to get conclusion if the image (extremely fresh, fresh, relatively fresh, not fresh, or awfully not fresh), mackerel not freshness percentage, and mackerel dead interval. This research used 150 images of mackerel, from the fresh ones to the bad ones. The results showed that 125 images matched $83.333 \%$ percentage of accuracy system and 25 images did not.
\end{abstract}

Keyword : Mackerel Eyes, Digital Image Processing, Least Square Method.

\section{Pendahuluan}

Bidang perikanan di Indonesia khususnya di Sulawesi Utara merupakan salah satu bidang yang banyak menggunakan kecanggihan teknologi, walaupun pada beberapa bagian masih memanfaatkan penilaian manusia dalam menentukan mutu kesegaran ikan. Secara umum ikan diperdagangkan dalam 
keadaan sudah mati juga seringkali dalam keadaan masih hidup . Penurunan kualitas ikan dapat dilihat dari perubahan warna kulit ikan, mata, insang, dan tekstur daging ikan. Perubahan-perubahan tersebut disebabkan oleh adanya aktivitas enzim, kimiawi, dan bakteri didalamnya sehingga menyebabkan ikan tersebut tidak layak diperdagangkan apalagi dikonsumsi oleh manusia [1].

Citra ikan yang mengalami penurunan kualitas dapat diamati berdasarkan bentuk, polah tubuh ikan, beserta perubahan ciri-cirinya. Pengidentifikasian kualitas ikan menggunakan pendekatan pengolahan citra digital, dengan demikian pengenalan terhadap perubahan warna citra ikan akan lebih akurat[2]. Pada penelitian yang dilakukan oleh Mandagi, Latumakulita, dan Rindengan (2015)[3] dapat diamati perubahan warna pada terumbu karang yang rusak dengan pendekatan pengolahan citra digital menggunakan metode kuadrat terkecil, sedangkan Latumakulita (2013) [4] dapat diamati rumus pembusukan ikan dengan metode curve fitting. Dalam penelitian ini akan dicoba dibangun suatu sistem aplikasi penentuan tingkat kesegaran ikan dengan proses identifikasi atau pengenalan mata ikan berdasarkan ciri warna yang tampak pada citra mata ikan menggunakan pengolahan citra digital serta metode kuadrat terkecil sebagai penentuan perumusan. Dari perumusan tersebut dapat diamati tingakat kesegaran ikan dengan bantuan komputer.

\section{Parameter Kesegaran Ikan}

Ikan yang baik adalah ikan yang masih segar. Ikan yang segar adalah ikan yang masih mempuyai sifat sama dengan ikan yang masih hidup, baik rupa, bau, rasa dan teksturnya.. Berdasarkan kesegaranya, ikan dapat digolongkan menjadi empat kelas mutu, yaitu ikan yang tingkat kesegaranya sangat baik sekali (prima), ikan yang kesegaranya baik (advanced), ikan yang kesegarannya mundur (sedang), dan ikan yang sudah tidak segar lagi (busuk)[1]. Segera setelah ikan mati, akan mengalami perubahan-perubahan yang mengarah pada pembusukan yang disebabkan oleh aktivitas bakteri, perubahan kimiawi yang ditimbulkan oleh enzim-enzim serta proses oksidasi lemak ikan olah udara[5].

\section{Citra Digital}

Citra, menurut kamus Webster, adalah "suatu representasi, kemiripan, atau imitasi dari suatu objek atau benda " [6]. Citra, dari sudut pandang matematis, merupakan fungsi (continue) dari intensitas cahaya pada bidang 2 dimensi. Secara matematis fungsi intensitas cahaya pada bidang dua dimensi disimbolkan dengan $f(x, y)$, yang dalam hal ini $(x, y)$, adalah koordinat pada bidang dua dimensi dan $f(x, y)$, adalah intensitas cahaya (brightness) pada titik $(x, y)$. Cahaya merupakan bentuk energi, dan tak berhingga maka intensitas cahaya bernilai 0 sampai tak berhingga [7]. Agar dapat di olah dengan komputer digital, maka suatu citra harus direpresentasikan secara numerik dengan nilai-nilai diskrit._Citra digital yang ukuranya $N$ x $M$ lazim dinyatakan dengan matriks yang berukuran $N$ baris dan $M$ kolom sebagai berikut:

$$
f(x, y)=\left[\begin{array}{cccc}
f(0,0) & f(0,1) & \ldots & f(0, M-1) \\
f(1,0) & f(1,1) & \ldots & f(1, M-1) \\
\vdots & \vdots & \ddots & \vdots \\
f(N-1,0) & f(N-1,1) & \ldots & f(N-1, M-1)
\end{array}\right]
$$

Indeks baris $(i)$ dan indeks kolom $(j)$ menyatakan suatu koordinat titik pada citra, sedangkan $f(i, j)$ merupakan intensitas (derajat keabuan) pada titik $(i, j)$

Bentuk matriks dari persamaan (1) di atas dapat dituliskan sebagai berikut:

$$
A=\left[\begin{array}{cccc}
a_{0.0} & a_{0.1} & \ldots & a_{0 . M-1} \\
a_{1.0} & a_{1.1} & \ldots & a_{0 . M-1} \\
\vdots & \vdots & \ddots & \vdots \\
a_{N-1.0} & a_{N-1.1} & \ldots & a_{N-1 . M-1}
\end{array}\right]
$$

Dengan $a_{i, j}=f(i, j)$, sehingga matriks pada persamaan (1) sama dengan matriks pada persamaan (2) [8].

\subsection{True Colour atau $R G B$}

Setiap pixel memiliki warna khusus, yang digambarkan dari nilai Red, Green dan Blue pada gambar tersebut. Setiap komponen memiliki nilai yang berada pada $0-255$, sehingga terdapat $255^{3}=16.777 .216$ kemungkinan warna yang berbeda pada suatu gambar. Dari jumlah bilangan bit yang dibutuhkan adalah 24, maka jenis gambar ini juga disebut gambar berwarna 24-bit [9]. 


\subsection{Grayscale}

Didalam tipe gambar grayscale, tidak terdapat pengaruh warna-warna lain seperti merah, biru ataupun hijau. Setiap pixel merupakan bayangan keabu-abuan, biasanya bernilai 0 (hitam) sampai 255 (putih).. Untuk melakukan perubahan suatu gambar full color menjadi suatu gambar grayscale atau skala keabuan, terdapat beberapa metode yang umum digunakan [9], yaitu : $\frac{(R+G+B)}{3}$

\subsection{Pemotongan ( Cropping )}

Cropping adalah pengolahan citra dengan kegiatan memotong satu bagian dari citra.

Rumus yang digunakan :

$\mathrm{x}^{\prime}=\mathrm{x}-\mathrm{xL}$ untuk $\mathrm{x}=\mathrm{xL}$ sampai $\mathrm{xR}$

$\mathrm{y}^{\prime}=\mathrm{y}-\mathrm{yT}$ untuk $\mathrm{y}=\mathrm{yT}$ sampai $\mathrm{yB}$

$(\mathrm{xL}, \mathrm{yT})$ dan $(\mathrm{xR}, \mathrm{yB})$ adalah koordinat titik pojok kiri atas dan pojok kanan bawah citra yang di-crop [2].

Ukuran citra menjadi : $\quad \mathrm{w}^{\prime}=\mathrm{xR}-\mathrm{xL}$

$$
\mathrm{h}^{\prime}=\mathrm{yB}-\mathrm{YT}
$$

\section{Pengertian UML}

UML (Unified Modelling Language) merupakan bahasa untuk visualisasi, spesifikasi, konstruksi serta dokumentasi. UML juga merupakan bahasa yang sifatnya standart untuk menggambarkan suatu proses, seperti proses bisnis, dan lain-lain. Dalam kerangka visualisasi, para pengembang menggunakan $U M L$ untuk mengkomunikasikan idenya kepada para pemrogram atau calon pengguna sistem atau aplikasi tertentu [10].

Ada banyak jenis model proses perangkat lunak yang menyarankan bagaimana untuk membangun perangkat lunak. model proses yang akan digunakan pada penelitian ini adalah linear sequential. Linear Sequential Model ini juga dikenal sebagai model air terjun atau siklus hidup klasik. Ini adalah model pertama yang pernah diformalkan, dan model proses lain didasarkan pada pendekatan pembangunan. Ini menunjukkan pendekatan yang sistematis dan sekuensial untuk pengembangan perangkat lunak [11]

\section{Metode Kuadrat Terkecil}

Metode kuadrat terkecil merupakan metode yang sering digunakan dalam teknik analisa regresi yang bertujuan untuk meminimumkan kuadrat kesalahan $e$ sehingga nilai regresinya mendekati nilai sesungguhnya. Dalam percobaan sains seringkali muncul kasus yang menghasilkan himpunan dari titiktitik data $\left(x_{i}, y_{i}\right), \ldots,\left(x_{N} y_{N}\right)$ dimana absis $\left\{x_{i}\right\}_{i=1}^{N}$ tertentu. Salah satu tujuan dari metode numerik yaitu menentukan formula $y=f(x)$ yang menghubungan semua variabel [13]. Pada kasus ini digunakan fungsi linier $y=f(x)=a x+$.Dalam percobaan pengukuran sering kita dapati kesalahan yang memenuhi $f\left(x_{i}\right)=y_{i}+e_{i}$, dimana $e_{i}$ adalah kesalahan atau error dalam pengukuran.

Pengukuran terhadap jauhnya garis $y=f(x)$ berada pada data

digunakan root-mean-square error, $E(f)=\left(\frac{1}{N} \sum_{i=1}^{N}\left(f\left(x_{i}\right)-y_{i}\right)^{2}\right)^{0.5}$

Koefisien dari garis least-squares $\quad y=a x+b$ yang merupakan solusi dari system linear yang dikenal sebagai persamaan normal atau normal equations :

$$
\begin{aligned}
& \left(\sum_{i=1}^{N} x_{i}{ }^{2}\right) a+\left(\sum_{i=1}^{N} x_{i}\right) \mathrm{b}=\sum_{i=1}^{N} x_{i} y_{i} \\
& \left(\sum_{i=1}^{N} x_{i}\right) a+N b=\sum_{i=1}^{N} y_{i}
\end{aligned}
$$

\section{Metodologi Penelitian}

\subsection{Analisis Data}

Data dalam penelitian ini menggunakan 10 sampel citra ikan selar. Citra mata ikan selar dimanfaatkaan sebagai input data untuk menghitung nilai rata-rata Grayscale yang memberikan informasi berupa nilai-nilai.. Hasil output nilai Grayscale diolah dengan metode kuadrat terkecil untuk menghitung tingkat kesegaran ikan yang kemudian dicocokan dengan data inferensi yang sebelumnya disimpan dalam data training dan output terakhir merupakan sebuah citra yang berisikan informasi keterangan tentang tingkat kesegaran ikan selar. 


\subsection{Metode Penelitian}

Langkah 1-6 menunjukan pengolahan citra untuk membangun sistem klasifikasi tingkat kesegaran ikan sedangkan langkah 9-12 menunjukan klasifikasi sistem aplikasi penentuan tingkat kesegaran ikan. langkah-langkahnya sebagai berikut :

1. Mengambil 150 data citra digital mata ikan selar dengan model warna $R G B$ yang berekstensi $J P G$ (Joint Photografhic Expert Group).

2. Dilakukan pengolahan citra dengan memotong (cropping ) pada bagian tepi mata ikan selar.

3. Penyamaan pixel citra digital.

4. Citra yang berekstensi $J P G$ dikonversi kebentuk citra yang berekstensi $P N G$ ( Portable Network Graphics).

5. Cari nilai rata-rata grayscale untuk setiap tekstur citra mata ikan selar dari citra mata ikan selar yang segar (prima) sampai tidak segar (busuk) kemudian buat persamaan.

6. Buat persamaan regresinya dengan metode kuadrat terkecil kemudian disimpan sebagai data training

7. Input citra pada sistem aplikasi.

8. Konversi $R G B$ ke Grayscale.

9. Tampilkan Histogram Citra $R G B$ dan Grayscale

10. Perumusan tingkat kesegaran ikan dengan metode kuadrat terkecil berdasarkan nilai rata-rata citra digital mata ikan selar.

11. Menyamakan data uji dengan data training citra yang sudah disimpan sebelumnya.

12. Menentukan dan menyimpulkan tingkat kesegaran ikan dengan perumusan dari inferensi data sebelumya

\subsection{Perancangan Sistem}

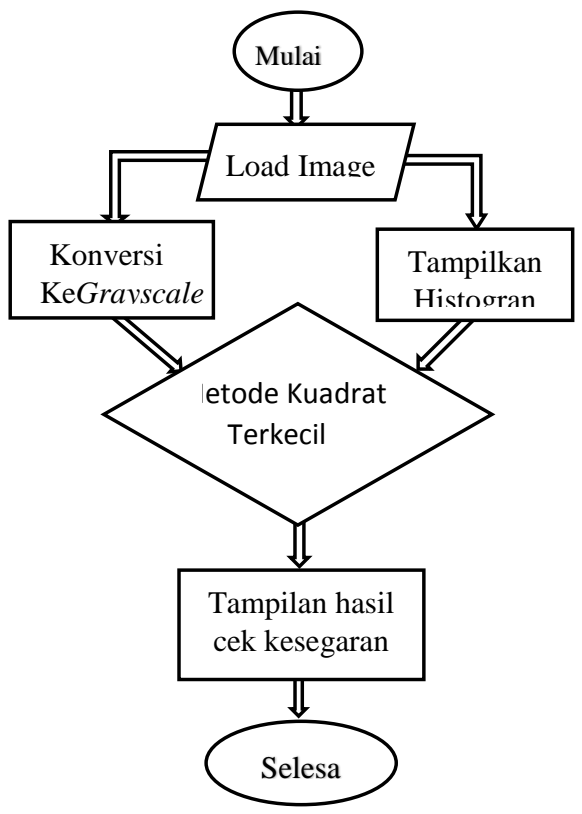

Gambar 1. Flowchart aplikasi deteksi kesegaran ikan

\section{Hasil Pembahasan}

Proses pengolahan citra dalam penelitian ini terdiri input gambar dan membaca matriks citra, melakukan cropping, resize, dan konversi citra yang dilakukan dengan software matematika.

\subsection{Pengolahan Cita}

\subsubsection{Input Citra}

Pada penelitian ini diamati 10 sampel ikan masing-masing difoto setiap 1 jam (60 menit) selama $15 \mathrm{jam}$. Citra digital ikan diperoleh dengan model warna $R G B$ ( Red, Green Blue), berekstensi PNG ( Portable Network Graphics) di-input dan ditampilkan dalam bentuk matriks $\mathrm{m} x \mathrm{n}$, sesuai dengan ukuran gambar tersebut pada bagian mata ikan.

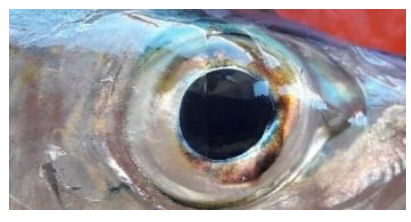

Gambar 2. Citra Original 


\subsubsection{Cropping Citra}

Setelah Citra digital mata ikan selar dengan model warna $R G B$ yang berekstensi $J P G$ (Joint Photografhic Expert Group) berhasil kita input, selanjutnya citra tersebut kita lakukan pemotongan (cropping) pada bagian tepi mata ikan dan disimpan dengan format citra yang berekstensi PNG ( Portable Network Graphics), maka diperoleh citra hasil cropping seperti pada table 1.

\subsubsection{Resize Citra}

Setelah proses pembacaan matriks tadi, akan mengahasilkan matriks citra digital dengan nilai piksel antara $0-255$ dan ukuran citra yang berbeda-beda pada dimensi warna $R G B$, sehingga mempermudah proses selanjutnya, maka perlu dilakukan proses resize untuk menyamakan semua ukuran citra digital dengan perintah 'imresize'.

\subsubsection{Koversi Citra RGB ke Grayscale}

Citra matriks $R G B$ hasil resize dikonversi ke matriks citra grayscale menggunakan perintah "'RGB2gray', sehingga diperoleh citra dengan model warna citra grayscale yang ditunjukan pada gambar 3. Proses perubahan citra $R G B$ ke grayscale.

\subsection{Analisis Citra}

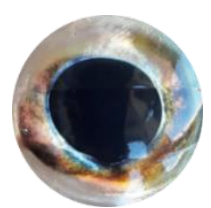

(a)Citra $R G B$

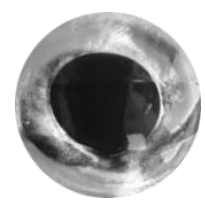

(b)Citra

Grayscale

Gambar 3. Perubahan Citra $R G B$ ke Grayscale

Sebelum membuat program utama, perlu dibuat data training sebagai penyimpanan data perhitungan tekstur citra yang menjadi pembanding untuk citra pengujian sehingga didapatkan kesimpulan untuk citra pengujian tersebut apakah termasuk citra ikan yang segar atau tidak segar.

Pembuatan data training menggunakan 10 sampel ikan yang dibiarkan pada saat masih segar sampai tidak segar atau membusuk. masing-masing variable dinyatakan sebagai $x_{1}, x_{2}, x_{3}, x_{4}, x_{5}, x_{6}, x_{7}, x_{8}, x_{9}, x_{10}$ dengan range warna 1-15 per jam yang merupakan pengukuran dari proses perubahan warna pada citra mata ikan atau perubahan tingkat kesegaran ikan, semakin warna mata ikan itu menguning maka ikan itu berada dalam kondisi yang tidak segar atau busuk. Kemudian masing - masing warna dihitung nilai rata - rata Grayscale dengan sistem perangkat lunak "Rata_rataGambar", dimana nilai rata-rata warna $R G B$ merupakan variable $x_{1}, x_{2}, x_{3}, x_{4}, x_{5}, x_{6}, x_{7}, x_{8}, x_{9}, x_{10}$ dan range warna 1-15 merupakan variable y sehingga diperoleh nilai rata-rata warna Grayscale.

Berdasarkan hasil nilai masing-masing range tersebut, dirata-ratakan jumlah warna grayscale $x_{1}, x_{2}, x_{3}, x_{4}, x_{5}, x_{6}, x_{7}, x_{8}, x_{9}, x_{10}$, kemudian diolah dengan metode kuadraat terkecil, sedemikian sehingga menghasilkan perumusan yang nantinya disimpan sebagai data training dan akan membantu dalam penentuan tingkat kesegaran ikan selar. Hasil perhitungan rata-rata Grayscale adalah sebagai berikut:

$a 81508.56+b 1083.671=7725.594$

$a 1083.671+15 b=120$

dalam bentuk persamaan matriks :

$$
\left[\begin{array}{cc}
81508.56 & 1083.671 \\
1083.671 & 15
\end{array}\right]\left[\begin{array}{l}
a \\
b
\end{array}\right]=\left[\begin{array}{c}
7725.594 \\
120
\end{array}\right]
$$

$a=\frac{15(7725.594)-(1083.671)(120)}{15(81508.56)-(1083.671)^{2}}=\frac{-14156.6}{48285.97}=-0.293$

$b=\frac{(120)(81508.56)-(1083.671)(7725.594)}{15(81508.56)-(1067.718)^{2}}=\frac{1409027}{48285.97}=29.180$

Diperoleh persamaan ; $\quad y=-0.293 x+29.180$

Setelah diperoleh persamaan linear dari perhitungan klasifikasi kesegaran ikan selar, maka diperoleh klasifikasi kesegaran ikan selar berdasarkan nilai Y pada perhitungan rata-rata gambar grayscale seperti pada table 1. 
Tabel 1. Klasifikasi Kesegaran Ikan Selar

\begin{tabular}{|l|l|c|c|}
\hline No & Klasifikasi Kesegaran & $\begin{array}{c}\text { Lama waktu } \\
\text { Ikan Mati }\end{array}$ & Keterangan \\
\hline 1 & $\mathrm{Y} \leq 4.4399$ & $0-3$ Jam & Sangat Segar \\
\hline 2 & $4.4399 \leq \mathrm{Y} \leq 6.4069$ & $4-6$ Jam & Segar \\
\hline 3 & $6.4069 \leq \mathrm{Y} \leq 8.3376$ & $7-9$ Jam & Cukup Segar \\
\hline 4 & $8.3376 \leq \mathrm{Y} \leq 12.6255$ & $10-12 \mathrm{Jam}$ & Tidak Segar \\
\hline 5 & $\geq 12.6255$ & $13-15$ Jam & Sangat Tidak Segar \\
\hline
\end{tabular}

Dari table perhitungan error klasifikasi kesegaran ikan maka diperoleh penyimpangan data gambar berdasarkan pengambilan data/jam pada perumusan klasifikasi kesegaran ikan ini adalah 0.212 jam dari jam pertama ke jam berikutnya.

\subsection{Sistem Aplikasi}

Implementasi perangkat lunak metode kuadrat terkecil dalam penetuan tingkat kesegaran ikan selar terdiri dari tampilan hasil rancangan dan penulisan program terdiri dari halaman depan , tampilan utama analisis data, dan informasi tentang suatu citra.

Halaman depan merupakan tampilan awal saat sistem dijalankan. Pada halaman depan ini terdapat judul dari aplikasi yang telah dibuat yaitu, "Aplikasi Penentuan Tingkat Kesegaran Ikan Selar Menggunakan Pengolahan Citra Digital Dengan Metode Kuadarat Terkecil”. Halaman depan ini terdapat edit text ' username' dan 'password' serta pussbutton 'login' yang harus diisi dulu sebelum masuk pada sistem utama. Jika login berhasil maka sistem utama akan ditampilkan. Tampilan halaman depan dapat dilihat pada gambar 4 .

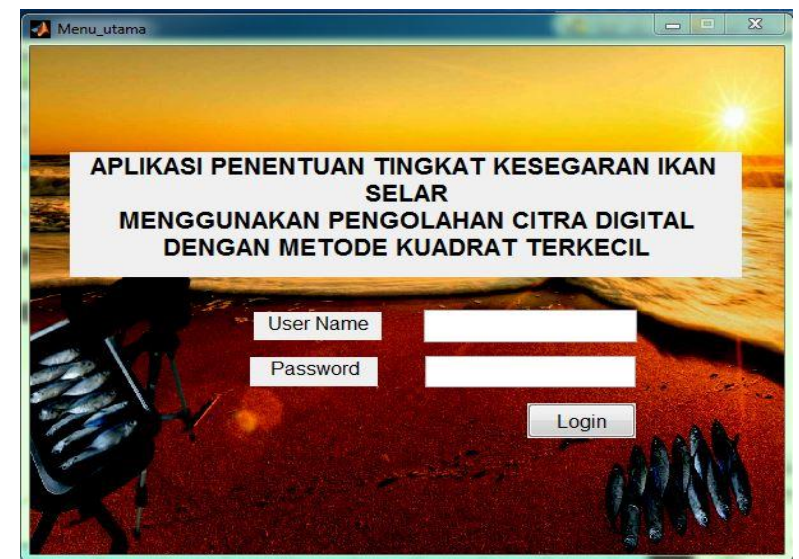

Gambar 4. Tampilan Halaman Depan

\subsubsection{Tampilan Sistem Utama}

Tampilan sistem utama merupakan tampilan analisis suatu citra digital dengan metode kuadrat terkecil. Tampilan sistem utama dapat dilihat pada gambar 5.

Pada bagian ini terdapat tampilan menubar dan tampilan kerja sistem aplikasi. Tampilan menubar terdiri dari menu load image, menu proses, menu remove, , menu about, dan menu close yang masingmasing memiliki fungsi, yaitu; menu load image berfungsi untuk menampilkan file citra, menu proses berfungsi untuk menganalisis citra, menu remove berfungsi untuk menghapus citra, menu about berfungsi untuk menampilkan informasi citra, dan menu close berfungsi untuk keluar dari sistem aplikasi.

Pada tampilan kerja sistem aplikasi ini juga terdapat lima panel yaitu panel original image yang berfungsi untuk menampilkan citra original. Panel grayscale berfungsi untuk menampilkan citra grayscale, panel image histogram berfungsi untuk menampilkan histogram citra ( grayscale histogram, red histogram, green histogram, dan blue histogram). Panel info berfungsi untuk menampilkan informasi suatu citra (nama file, ukuran, panjang, lebar, bit). Panel kesimpulan pada tampilan kerja sistem aplikasi ini berfungsi untuk menampilkan variable bebas $\mathrm{Y}$, menampilkan persentase keakurasian sistem, dan menampilkan keputusan akhir apakah ikan itu (sangat segar, segar, cukup segar, tidak segar, sangat tidak segar) diikuti dengan keputusan berapa lama waktu ikan itu mati. 


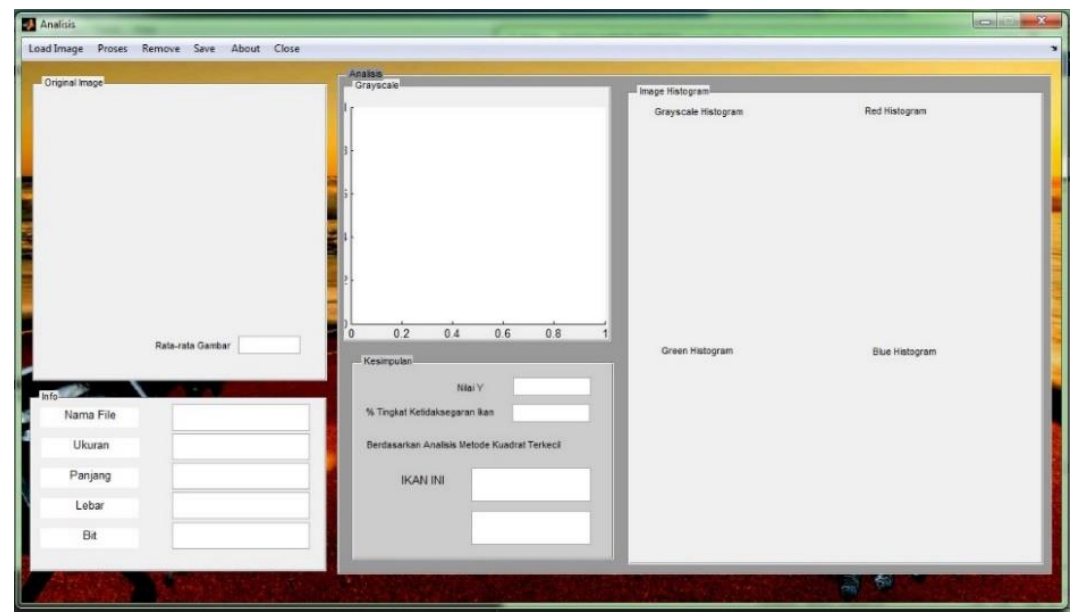

Gambar 5. Tampilan Sistem Utama

Langkah-langkah yang dibuat dalam perancangan sistem ini yaitu:

\section{- Load image}

Analisis

(a) Menu load image

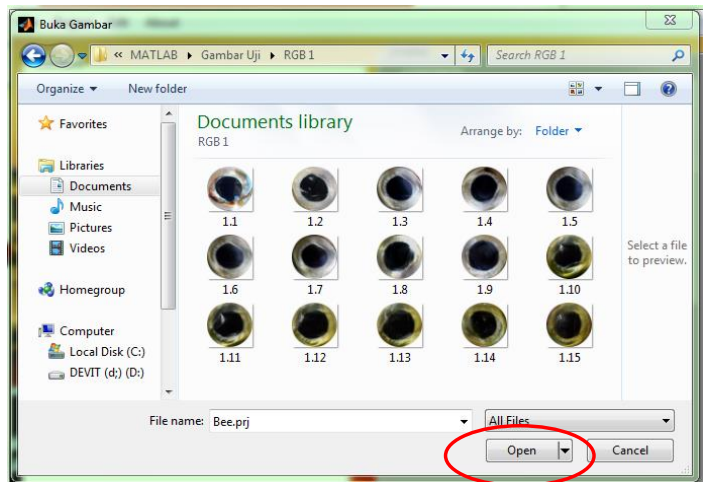

(b) Kotak dialog

Gambar 6. Tampilan Untuk Membuka dan Menampilkan File

Load image digunakan untuk memilih citra yang nantinya akan disimpan kedalam data training. Pada bagian proses load ini, hanya file citra yan berekstensi *.png yang dapat di-load dan ditampilkan pada program. Untuk menampilkan file citra kita pilih 'load image' pada menubar maka akan ditampilkan kotak dialog untuk memilih file citra yang akan diuji. Pada kotak dialog tersebut pilih 'open' untuk proses input file citra, maka secara langsung dilakukan analisis citra. Citra hasil analisis akan ditampilkan pada tempat yang telah disediakan dalam bentuk citra grayscale dan histrogram citra, seperti pada gambar 7.

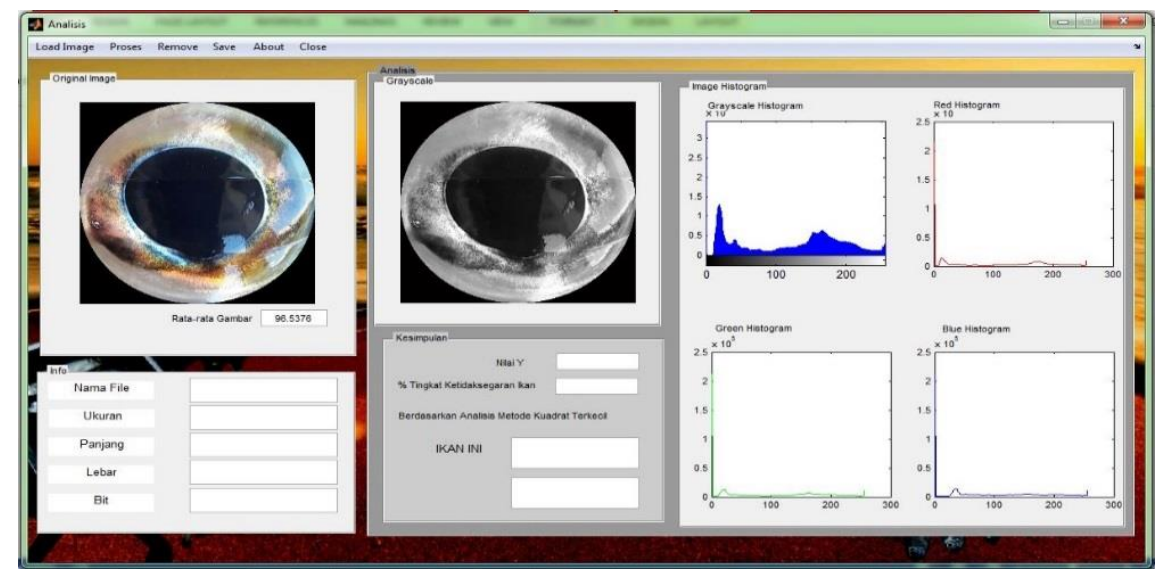

Gambar 7. Tampilan Citra Setelah File berhasil dibuka

- Konversi Grayscale

Pada bagian ini citra $R G B$ yang berekstensi *.png akan dikonversi ke grayscale secara otomatis dan disimpan sebagai citra uji. Citra $R G B$ yang dikonversi ke citra grayscale dapat dilihat pada gambar 8 . 


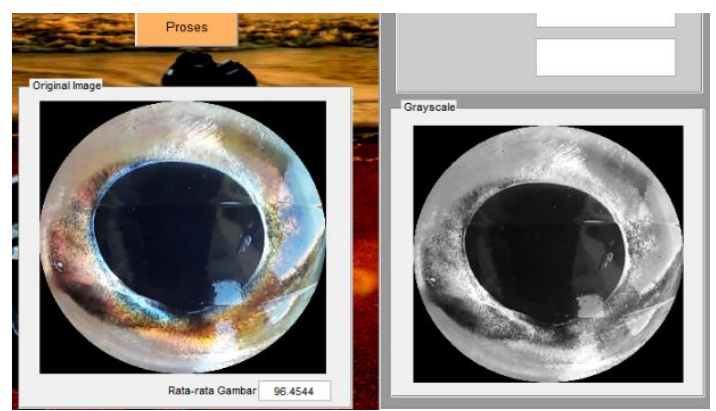

Gambar 8.Tampilan konversi citra ke Grayscale

\subsubsection{Histogram Citra $R G B$ dan Grayscale}

Pada proses ini menampilkan informasi tentang kepadatan warna suatu citra yang ditampilkan dalam bentuk histogram. Sumbu x (absis) menunjukan tingkat kepadatan warna dan y (ordinat) menunjukan frekuensi kemunculan titik, seperti pada gambar 9.

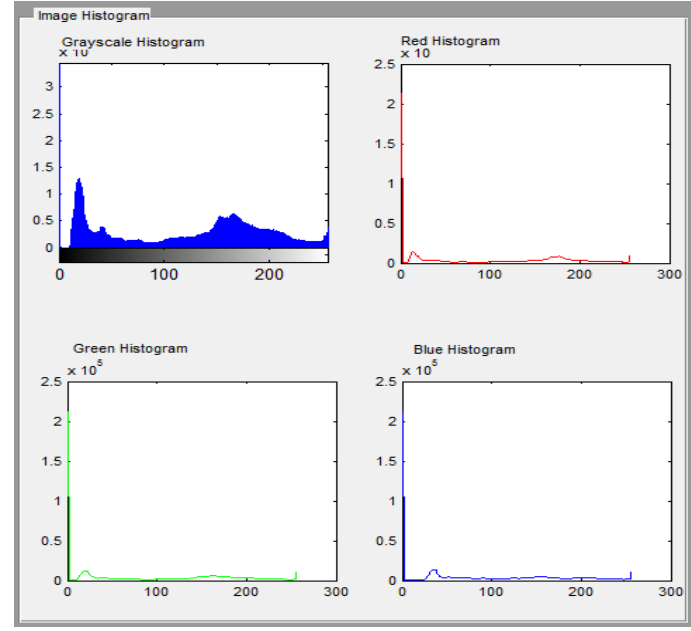

Gambar 9. Tampilan Histogram Citra $R G B$ dan Grayscale

\subsubsection{Perhitungan Metode Kuadrat Terkecil}

Proses selanjutnya adalah analisis citra dengan metode kuadrat terkecil, dimana setelah citra telah terkonversi ke grayscale dan dihitung histogramnya, kemudian kita pilih pushbutton 'proses' pada menubar maka akan ditampilkan nilai variable bebas dan persentase nilai kesegarannya. Proses terakhir yaitu ditampilkan keputusan apakah ikan itu ( sangat segar, segar,cukup segar, tidak segar, dan sangat tidak segar) dan diikuti dengan keputusan berapa lama ikan itu mati seperti pada gambar 10.

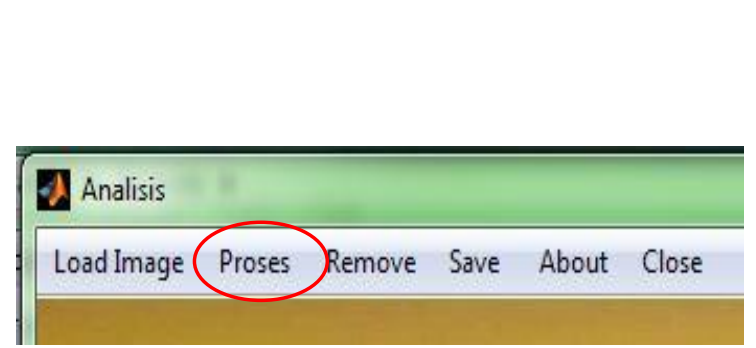

(a) Menu Proses

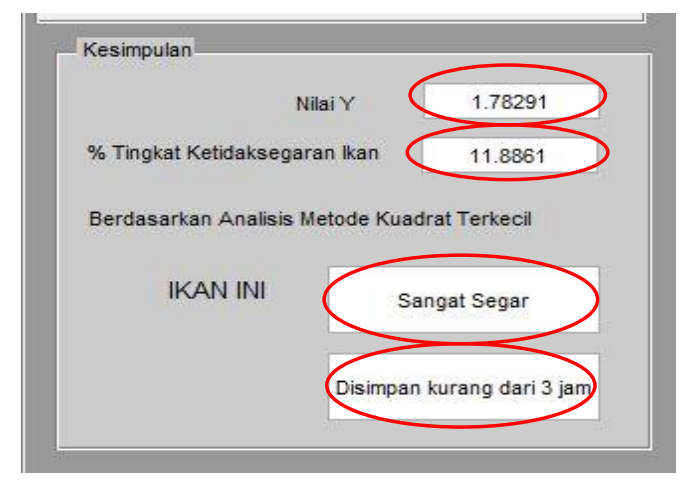

(b) Kesimpulan

\section{Gambar 10. Tampilan Hasil Cek Kesegaran}

\subsubsection{Remove}

Pada sistem aplikasi ini jika kita ingin menginput file citra baru maka citra yang sementara ditampilkan akan terhapus digantikan file citra yang baru, tapi kita juga bisa menghapus file citra yang ada 
pada tampilan sistem dengan memilih pushbutton 'remove' pada menu bar maka citra yang ditampilkan secara langsung akan terhapus, seperti pada gambar 11.

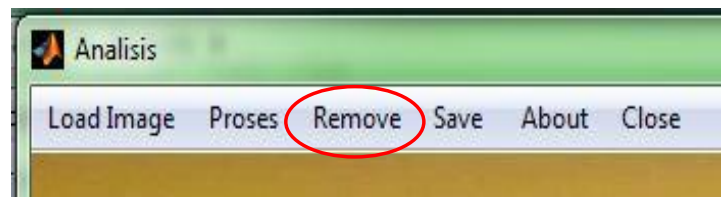

Gambar 11. Menu Remove

\subsubsection{About}

Pada bagian ini kita akan menampilkan informasi tentang suatu citra yang berisikan nama file, ukuran, panjang, lebar, dan bit. Informasi citra diperoleh dengan memilih pushbuttn 'about' pada menubar maka akan ditampilkan nama file, ukuran , panjang, lebar, dan bit, seperti pada gambar 12.

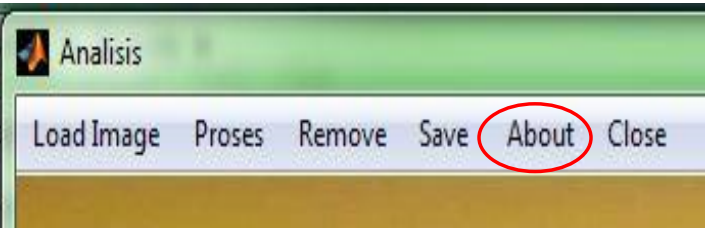

(a) Menu about

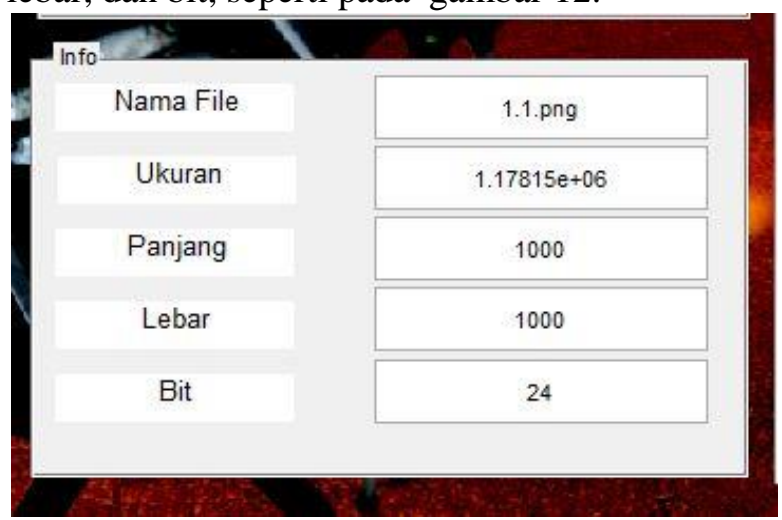

(b) Informasi citra

Gambar 12. Tampilan Informasi Citra

\subsubsection{Close}

Pada proses ini dilakukan apabila kita ingin keluar dari tampilan sistem utama, maka yang kita pilih adalah menu 'close' pada tampilan menu bar, seperti pada gambar 13.

Analisis
Load Image Proses Remove Save About Close

Gambar 13. Menu close

\subsection{Pengujian Sistem}

Pada penelitian ini, tahap pengujian sistem akan dilakukan dengan pengujian terhadap 150 citra ikan selar yang berekstensi *.png. dimana 150 citra tersebut diperoleh dari pengambilan citra mata ikan selar sebanyak 10 sampel ikan dan difoto setiap satu jam selama 15 jam dari ikan itu masih dalam kondisi segar hingga ikan itu membusuk. Dari 150 data citra mata ikan selar tersebut dilakukan pengolahan citra dengan melakukan penyamaan ukuran pixelnya dan pemotongan terhadap bagian mata ikan, setelah pengolahan citra tersebut, citra yang berekstensi *.png dikonversi ke bentuk grayscale selanjutnya ditampilkan histogram $R G B$ dan grayscale-nya kemudian dilakukan perhitungan dan analisis dengan metode kuadrat terkecil. Pada bagian terakhir dilakukan pencocokan citra hasil input dengan citra yang sudah disimpan sebagai data training. Perhitungan dan analisis metode kuadrat terkecil tersebut mampu mendeteksi perubahan warna citra dengan membandingkan data range nilai rata-rata tekstur mata ikan yang menjadi acuan dalam menentukan tingkat kesegaran suatu ikan selar. Dengan nilai $\mathrm{N}$ adalah jumlah seluruh citra mata ikan selar yang diujikan yaitu 150 citra yang terdiri dari 5 kelas warna, maka dapat dihitung tingkat akurasinya sepeti pada tabel 2.

Dari table akurasi sistem tersebut didapatkan tingkat akurasi untuk identifikasi kesegaran ikan selar berdasarkan perhitungan tekstur citra dengan metode kuadrat terkecil yaitu mencapai 83,333\%. 
Tabel 2. Akurasi Sistem

\begin{tabular}{|l|l|l|}
\hline Input & Sesuai & Tidak Sesuai \\
\hline Ikan & 125 & 25 \\
\hline Akurasi (\%) & \multicolumn{2}{|c|}{$\frac{125}{150} \times 100=83,333 \%$} \\
\hline
\end{tabular}

\section{Kesimpulan}

Berdasarkan hasil penelitian yang telah dilakukan dapat diambil kesimpulan sebagai berikut :

a. Aplikasi ini dapat dikembangkan dengan melakukan penelitian menggunakan metode lain untuk menentukan kesegaran suatu ikan.

b. Berdasarkan pengujian 150 sampel citra mata ikan dari aplikasi ini mempunyai persentase tingkat keberhasilan yang baik, untuk pengujian data uji citra mata ikan dengan pencocokan citra yang disimpan sebagai data training diperoleh 122 citra mata ikan selar yang sesuai dan 28 citra mata ikan selar yang tidak sesuai . sehingga persentase tingkat keberhasilan Aplikasi penentuan tingkat kesegaran ikan selar menggunkan pengolahan citra digital berdasarkan analisis perubahan warna mata ikan dengan metode kuadrat terkecil yaitu sebesar $81,333 \%$

\section{Daftar Pustaka}

[1] Adawyah, R. 2014. Pengolahan dan Pengawetan Ikan. Bumi Aksara.Jakarta.

[2] Kusumaningsih, I. 2009. Ekstraksi Ciri Warna, Bentuk, dan Tekstur Untuk Temu Kembali Citra Hewan [Skripsi]. FMIPA IPB, Bogor

[3] Mandagi, A., L, Latumakulita, dan A. Rindengan. 2015. Identifikasi Tingkat Kesehatan Karang, Berdasarkan Coral Health Chart Menggunakan Pengolahan Citra Digital Dan Metode Kuadrat Terkecil. Jurnal de Cartesian 4(1):42-50. [http://ejournal.unsrat.ac.id/index.php/decartesian/article/view/7590]

[4] Latumakulita, L. 2013. Penentuan Rumus Pembusukan Ikan Menggunakan Metode Curve Fitting Dengan Pendekatan Pengolahan Citra Terhadap Digital Citra Insang Ikan. Jurnal Matematika. $2(2): 1-4$

[5] Ilyas, S. 1983. Teknology Refrigasi Hasil Perikanan Jilid I. Liberty. Yogyakarta

[6] Hestiningsih, I. 2009, Pengolahan Citra, http:///images.moedy9.multiply.multiplycontent.com/attachment/0/SMuuNwoKCBkAAHPHjZk1/P engolahan\%20Citra.pdf?nmid=115281461 [Diakses 6 Januari 2016]

[7] Munir, R. 2004. Pengolahan Citra Digital. Informatika. Bandung.

[8] Gonzalez R.C., R.E. Woods., and S.L. Eddins. 2008. Digital Image Processing 3rd Edition. Pearson Prentice Hall, New Jersey.

[9] McAndrew, A. 2004. An Introduction to Digital Image Processing with Matlab. School of Computer Science and Mathematics Victoria University of Technology.

[10] Nugroho, A. 2005a. Analisis dan Perancangan Sistem Informasi dengan Metodologi Berorientasi Objek. Informatika: Bandung.

[11] Nugroho, A, 2005b. Rational Rose untuk Pemodelan Berorientasi Objek. Informatika: Bandung.

[12] Yahya, K., dan Y. Melita. 2011. Aplikasi Kompresi Citra Digital Menggunakan Teknik Kompresi JPEG Dengan Fungsi GUI pada MATLAB. Jurnal Teknika. 3(2): 461-468

[13] Mathews, J. and K.Fink. 1999. Numerical Methods Using MATLAB Third Edition. Prentice Hall Upper Saddle River. USA. 